\title{
An inventory of useful threatened plant species in Vhembe Biosphere Reserve, Limpopo Province, South Africa
}

\author{
LUAMBO JEFFREY RAMARUMO", ALFRED MAROYI \\ Department of Botany, Faculty of Sciences and Agriculture, University of Fort Hare. Private Bag X1314, Alice, 5700, South Africa. \\ Tel.: +27-72-550 5589, `email: luambo@safrica.com
}

Manuscript received: 10 April 2020. Revision accepted: 22 April 2020.

\begin{abstract}
Ramarumo LJ, Maroyi A. 2020. An inventory of useful threatened plant species in Vhembe Biosphere Reserve, Limpopo Province, South Africa. Biodiversitas 21: 2146-2158. Scientists and conservation managers are seeking to understand and monitor plant species that are likely to be on the verge of extinction risk. Monitoring of threatened plants' extinction risk can be better achieved through insights about indigenous knowledge dynamics associated with those species. This study aimed to document detailed information about useful threatened plant species in the Vhembe Biosphere Reserve, Limpopo Province, South Africa. Data was collected through interviews with 203 participants and literally counting of individuals as per the IUCN's Red List Criteria. A total of 13 useful and native threatened plants belonging to 12 families were recorded. The majority of the threatened plant species were being used for medicinal purposes only (46.0\%) followed by the mixture of medicinal and ornamentals $(23.0 \%)$. The frequently cited useful threatened species with UV > 0.024, RFC > 0.059 and FL > 5.911\%, includes Asparagus sekukuniensis, Bowiea volubilis, Brackenridgea zanguebarica, Ocotea bullata, Rhynchosia vendae, Siphonochilus aethiopicus and Warburgia salutaris. About $47.0 \%$ of the recorded useful threatened plants were distributed in remote areas of the Thathe Vondo and its surroundings. Threatened plants with the population size $<100$ adult individuals constitute an overall of $61.54 \%$ of all the recorded species. The current study provides substantial information about useful threatened plant species in the studied region. Detailed information about threatened plant species remains fundamental for making informed decisions that are important for managing species of conservation concern.
\end{abstract}

Keywords: Distribution, population size, useful threatened plant species, utilization, Vhembe Biosphere Reserve

Abbreviations: FL: Fidelity level, IUCN: International Union for Conservation of Nature, RFL: Relative frequency of citations, UV: Use value

\section{INTRODUCTION}

Over the past decades, global conservation of threatened plant diversity has gradually increased and governments throughout the world have vowed to make the conservation of those plant species mandatory (Ma et al. 2013; Walsh et al. 2013; Pimm et al. 2014; Pimm and Joppa 2015; Heywood 2015; Rossi et al. 2016; Bailey et al. 2016; Dzerefos et al. 2017; Xu et al. 2017). Scientists and conservation managers around the globe are varying with regard to the predictions of extinction rates (Smith et al. 1993; Keith et al. 2008; De Vos et al. 2015; Ceballos et al. 2015). Lenzen et al. (2012) and Pimm et al. (2014), reiterated that the present rate of plant species extinction is roughly 1000 times than usual rates. However, ValienteBanuet et al. (2015), argued that real and empirical extinction rate is likely to exceed the predicted rates. Climate change and human disturbance such as overexploitation of plant resources, agricultural land expansion, development of new settlement, deforestation and afforestation of exotic plants for commercial are considered amongst the main drivers of habitat loss and species extinction (Bellard et al. 2016; Graham et al. 2016; Leitao et al. 2016; Brose et al. 2017; Ceballos et al. 2017).

Internationally, the mandates and authority for categorizing plants as threatened species are carried out by the International Union for Conservation of Nature (IUCN), whereas, in South Africa, those mandates are fostered by the South African National Biodiversity Institute (SANBI), an affiliate body of the IUCN (Moraswi et al. 2019). Threatened plant species refer to any species that have been evaluated using the International Union for Conservation of Nature (IUCN)'s version 3.1 of the Red List Categories and Criteria and therefore, categorized as either Vulnerable (VU), Endangered (EN) or Critical Endangered (CR) (IUCN 2012). Useful plants are defined as the species that are utilized by humans to fulfil their needs (Williams et al. 2013; Ramarumo et al. 2020). Threatened plants are protected internationally by treaties and conventions (Cock et al. 2010; de Oliveira et al. 2011). The United Nations Convention on Biological Diversity (CBD) gives particular relevance to the use of genetic resources and the associated traditional knowledge (Talaat 2013). The whole protocol is dedicated to the access of resources, fair and equitable sharing of benefits from their utilization (Buck and Hamilton 2011). In South Africa, the protection of threatened plant species is mandatory under various regulations, including the National Environmental Management: Biodiversity Act No. 10 of 2004, National Environmental Management Act No. 107 of 1999 and the Conservation of Agricultural Resources Act No. 43 of 1983 
(Cousins et al. 2010; Badenhorst 2011; Bamigboye et al. 2017).

The Soutpansberg Region of the Vhembe Biosphere Reserve, in the Limpopo Province is considered one of the key biodiversity hotspot in South Africa (Kirchhof et al. 2010; Hahn 2017; Hahn 2019; Bamigboye and Tshisikhawe 2020), but there is a dearth of information about useful threatened plant species in this region. There are no doubts that some threatened plant species are extant and useful in this region. Yet, detailed information about their values to local peoples' livelihoods, population size, distribution range, and conservation status have not been comprehensively studied. Insights about useful threatened plant species could lead to the betterment of their management and policy-revision. Biró et al. (2014) uttered that indigenous knowledge associated with useful threatened plant species have not been comprehensively studied in South Africa and worldwide, whereas, Manne and Pimm (2001) argued that conservation managers, policy-makers and scientists are seeking to understand and monitor plant species that are likely to be on the verge of extinction risk. Therefore, better monitoring, management, and prediction of threatened plants' extinction risk can only be achieved through better insights about indigenous knowledge dynamics associated with those species (Von Glasenapp and Thornton 2011).

Insights about threatened plant species' use-values, population size, distribution range, and present conservation status could provide better understanding of conservation need required for individual taxon. The current study aimed to document detailed information about useful threatened plant species in the Soutpansberg Region of the Vhembe Biosphere Reserve, Limpopo Province, South Africa. Thus, this study could provide baseline data required for policy-revision, monitoring, management, and either assessment or re-assessment of extinction risk on threatened plant species within the region and countrywide.

\section{MATERIALS AND METHODS}

\section{Study area}

Topography and geology

The current study was, held in the Soutpansberg Site of the Vhembe Biosphere Reserve, in the Limpopo Province, South Africa (Figure 1). Some parts of the study site are within the conservation area called Soutpansberg Biodiversity and Endemism Centre (Mostert et al. 2008; Taylor et al. 2013). The study area is located in the far northern part of the Limpopo Province in South Africa. Its surface area is approximately $6700 \mathrm{~km}^{2}$ (Hahn 2017), with an estimated population size of about 1393950 peoples in 2019 , of which $98 \%$ of them are the black ethnic groups (Vhembe District Municipality 2019), whom, the majority $(67.16 \%)$ of them speaks the Tshivenda language as their inborn language (Census 2011). This region is considered the getaway passage from South Africa to its neighboring countries that it shares the borders with, including Zimbabwe, Botswana, and Mozambique. The topographical zones of the study area range from $22^{\circ} 15^{\prime} 0 "$ to $23^{\circ} 45^{\prime} 0$ " South latitudes and $29^{\circ} 0^{\prime} 00^{\prime \prime}$ to $31^{\circ} 0^{\prime} 0^{\prime \prime}$ East longitudes, whereas, its elevation lies from 200 to $1748 \mathrm{~m}$ above the sea level (Hahn 2017). The geological formation of the region resembles volcanic and sedimentary succession with features that include Wylies Poort geological formation of the Soutpansberg Group, Kalahari Cratons, Bushveld Igneas Complexity, Karoo System and the Limpopo Archaean Cratons (Barton et al. 2006; Hahn 2011).

\section{Vegetation and climate}

The Soutpansberg Region of the Vhembe Biosphere Reserve can be described by its diverse and incessant vegetation mosaic range from the Soutpanberg Mountain Bushveld with some patches of grasslands and Afromatane Forest within, to the Semi-desert scrubland (Luseba and Tshisikhawe 2013; Hahn 2017). Some of the dominant plant species found in the Soutpansberg Arid Region included, Tribulus terrestris L., Grewia hexamita Burret and Terminalia prunioides M.A. Lawson, whereas, the some dominant forest plant species include, Xymalos monospora (Harv.) Baill., Kiggelaria africana L. and Rhoicissus tomentosa (Lam.) Wild \& R.B.Drumm (Mostert et al. 2008). Climatically, the Soutpansberg could be described by its seasonal variations in terms of rainfall and temperature. Usually, the Soutpansberg's average annual rainfalls range from $300 \mathrm{~mm}$ (Mpandeli 2014) in the winter season (spans from May to September) to $1874 \mathrm{~mm}$ (Hahn 2018) during the summer seasons (span from October to April). According to Hahn (2018), the average annual rainfall volume of the region diminished from the southern central regions where there is red-clay soil towards the northwestern site of the Soutpansberg. Generally, the regional annual temperatures range from $20^{\circ} \mathrm{C}$ in winter to $30^{\circ} \mathrm{C}$ during the summer season (Mostert et al. 2008).

\section{Socio-demographic information}

The total number of 203 participants took part in the current study, including laypeople $(41.3 \%)$, traditional health practitioners $(23.8 \%)$, farmers $(9.9 \%)$, escorts for traditional health practitioners $(16.2 \%)$, hunters $(5.2 \%)$ and environmentalists $(3.5 \%)$. Although the Soutpansberg has been labelled as one of special economic zones in South Africa, due to the availability of its underground coal reserves (Department of Trade and Industry 2017), its economic status still explicitly resembles poor reforms, with $90.8 \%$ of participants without tertiary educational qualifications. The unemployment rate $>53.9 \%$, with the majority of people $(57.5 \%)$ rely upon the government grants and parental support for livelihood and therefore, $58.9 \%$ of them seemed to earn an annual income of < US\$ 2880 (Figure 2). 


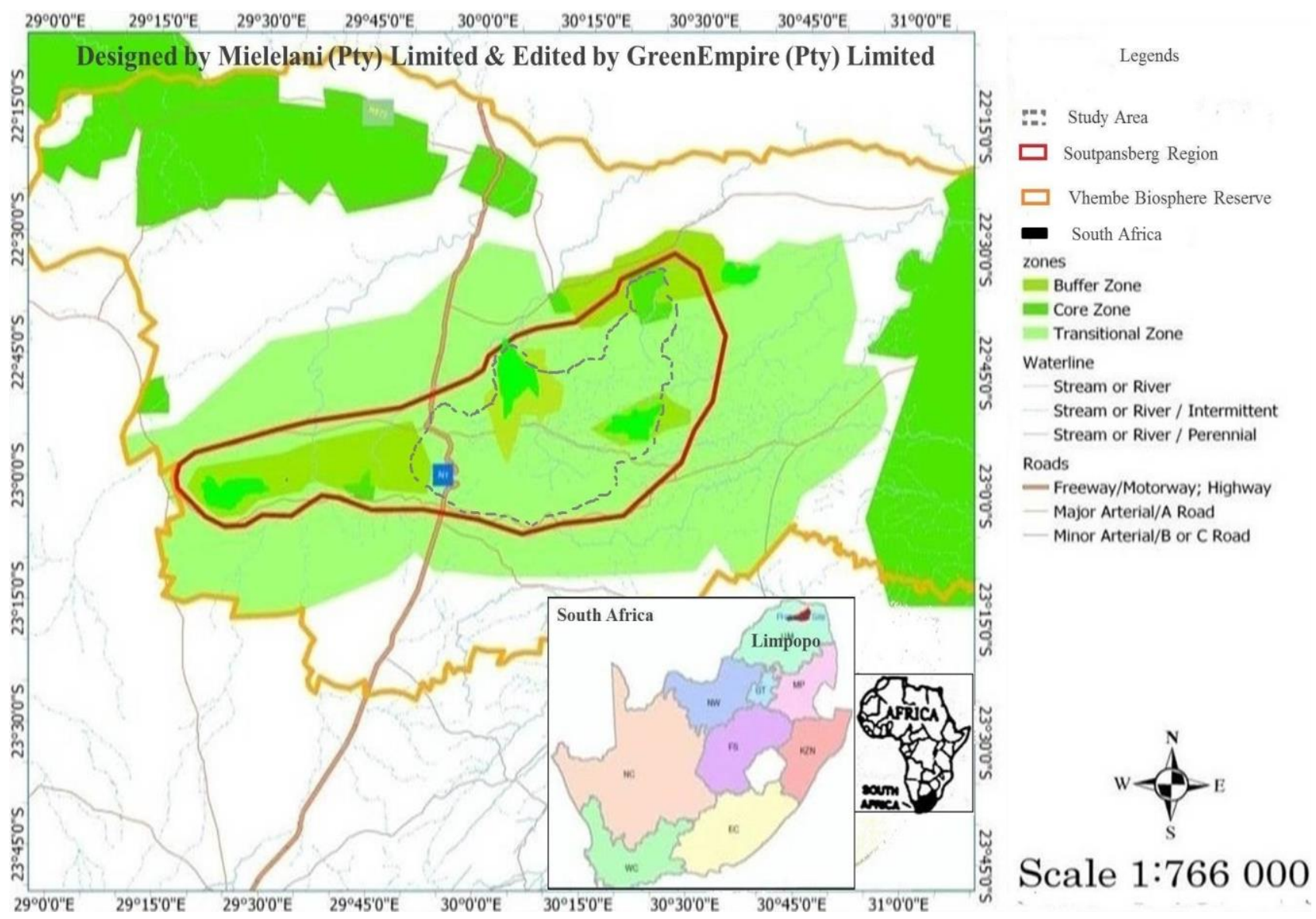

Figure 1. Locality map of the studied region in the Soutpansberg Site, Vhembe Biosphere Reserve, Limpopo Province, South Africa

\section{Methods \\ Data gathering}

Data collection was conducted over a period of 15 months, from August 2018 until October 2019. Information about useful threatened plant species in the Soutpansberg, Vhembe Biosphere Reserve, Limpopo Province in South Africa was acquired through Participatory Rural Appraisal (PRA) using semi-structured questionnaires in an interview with the total number of 203 individual participants (Figure 2). The small sample size or number of participants chosen was motivated by the duration taken during the interview (Flax et al. 2017). Participatory Rural Appraisal is considered an ideal research technique for exploration and documentation of information about useful natural resources (Chamber 1994; Weber and Ringold 2019) including threatened plant species. The University of Fort Hare's Research Ethics Committee reviewed the legitimacy of the current study and therefore, endorsed it with an Ethical Clearance Certificate of the reference number MAR031SRAM01, prior to the commencement of data collection. Pilot study was undertaken, prior to data sampling survey and its focus was to clearly explain the objectives of the study to all participants, testing the reliability of the questionnaires, and seeking permission to proceed with the current study from traditional leaders and private landowners. All the participants signed the written informed consent, stipulating that their participation could remain voluntary, they could freely quit participating at any time they wish, their acquittal could not penalize them in any way and their information could only be used for research purposes.

Participants were selected randomly during the community gathering and prior to them giving their informed consent. The randomly chosen participants included laypeople, traditional health practitioners, escorts for traditional health practitioners, farmers, hunters, and environmentalists, aged from 18 to 93 years old. The targeted recruits, involves both genders, with female participants constituting $58.3 \%$ and male $41.7 \%$ (Figure 2). To ensure confidentiality and smooth flow of information during the interview sessions, all participants were interviewed individually at their homesteads and therefore, all questionnaires were administered using the Tshivenda language, better understood by all people across the studied region. Furthermore, to ensure the high level of validity, authenticity, legitimacy, and veracity of the given responses by the recruits during the interview sessions, similar questions were posed to them all.

Data about threatened plants' population size across the studied region was gathered through literally counting of individuals per taxon. During sampling, only adult threatened plant individuals were targeted per taxon. This 
was influenced due to the fact that the IUCN's version 3.1 of the Red List Categories and Criteria stipulates that only adult individuals of species could be considered for the conservation status assessments (IUCN 2012). However, the current study was never intended to either assess or reassess the conservation status of threatened plant species in the studied region, instead, it was all about documentation for detailed information associated with useful threatened plants, including their international and national conservation status, as well as their coordinates of location for their distribution range and also their population size across the studied region. To avoid the re-counts of species during population survey, coordinates of location for all the counted adult individuals of every taxon were recorded using Global Positioning System (GPS) Reader Application (Dead Duck Software, Version 4.0) on Samsung Galaxy J2 Core (Model number SM-J260F/DS). Data about either their international or national conservation status was gathered from the IUCN Red List of Threatened Species (Version 2019-2) database and South African National Biodiversity Institute (SANBI) Red List of South African Plants (Version 2017.1) database. Data associated with the distribution and locations for the threatened plant species within the studied region were also recorded using the GPS Reader Application on Samsung Galaxy J2 Core. This could simplify the monitoring of threatened plant species within the studied region in the future.

\section{Specimen collections}

Sampled data were then supplemented by a guided field-inspection survey led by the participants who seemed to be more familiar with the exact locations of the target plant species, for identification and voucher specimen collection purposes. In South Africa, threatened plant

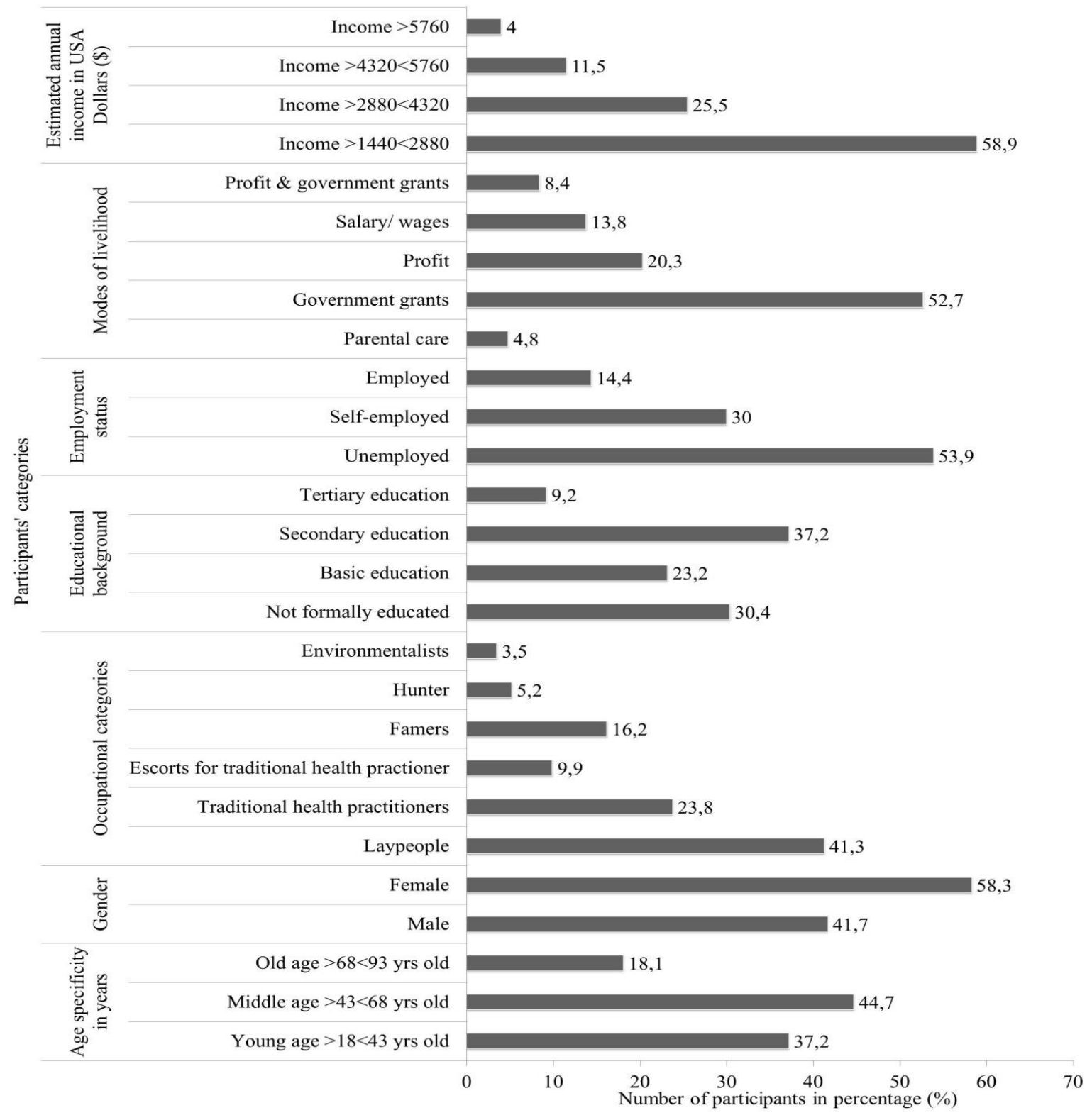

Figure 2. Participants' socio-demographic information 
species collection is regulated under the National Environmental Management: Biodiversity Act, 10 of 2004 (NEMBA) (Molewa 2007; Crouch et al. 2008), therefore, voucher specimen collection permit No. ZA/LP/100948 (Reference No. CPM/30877/2019) was issued by the Limpopo Provincial Department of Economic Development, Environment, and Tourism (LEDET). At first, participants identified the target plant species using their vernacular names and then, their botanical names were later authentically verified by trained taxonomists. Furthermore, the collected specimens were then prepared (dried and mounted), assigned the voucher code, and deposited in Botany Herbarium of the University of Venda.

\section{Data analysis}

Data gathered through the PRA during the interview with participants were analyzed qualitatively, using three ethnobotanical indices such as the use value (UV), relative frequency of citations (RFC), and fidelity level percentage (FL\%) (Atyosi et al. 2019). According to Al-Qur'an (2009) and Umair et al. (2017), UV indicates the relative importance regarding the utilization of the cited plant species, and it is determined using the following formula:

$$
U V_{\mathrm{i}}=\frac{\sum U_{\mathrm{i}}}{N^{x}}
$$

Wherein, the UV is considered to be the use-value of individual taxon, $\mathrm{U}$ : being the number of uses cited for that taxon and, therefore, $\mathrm{N}$ : represents the total number of recruits who cited the taxon (Phumthum et al. 2018; Shuaib et al. 2019). The relative frequency of citations (RFC), indicates local importance of every species within the studied region (Atyosi et al. 2019) and it is donated using the following formula:

$$
R F C=\frac{F C}{N}(0<\mathrm{RFC}<1)
$$

Wherein, RFC, referred to the relative frequency of citations, FC: denotes the total number of the recruits who cited the uses of individual taxon and, $\mathrm{N}$ : being the total number of all the recruits who took part in the current study (Ahmed et al. 2014; Kankara et al. 2015; Hussain et al. 2018). Fidelity level (FL) refers to the percentage of recruits who cited the use of certain threatened taxon within the studied region and it was determined using the formula adopted from Singh et al. (2019):

$$
F L(\%)=\frac{N_{p}}{N} \times 100 x
$$

Wherein, the FL (\%), denote fidelity level of percentage, $\mathrm{N}_{\mathrm{P}}$ : represents the number of recruits who cited the certain threatened taxon for the particular uses, whereas, $\mathrm{N}$, denote the total number of recruits who cited the uses of any threatened taxon (Andrade-Cetto et al. 2011; Ullah et al. 2014).

\section{RESULTS AND DISCUSSION}

\section{Conservation status}

The results obtained in the present study demonstrated the existence of 13 useful threatened plant species in the Soutpansberg Site of the Vhembe Biosphere Reserve, Limpopo Province in South Africa. Although the current study was only focused on adult threatened plants, species like Prunus africana (Hook.f.) Kalkman seemed to be of poor regeneration since no seedling was observed within the studied region. According to Tesfaye et al. (2010) and Jimu et al. (2013), poor regeneration of $P$. africana could be possibly influenced by seed predation, lack of suitable habitat for seed germination, and human. Only five species within the recorded threatened plants seemed to have the IUCN conservation status (Year 2019), ranging from the IUCN Category, VU to EN, and therefore, all the 13 recorded species contain the SANBI conservation status (Year 2017), including VU, EN, and CR (Figure 3 and Table 1). The IUCN's conservation status of plants is considered important for enforcing the international laws, including treaties and conventions, whereas, SANBI's conservation status enforces the national regulations (Raustiala and Victor 1996; Raustiala 1997; Messer 2010; Trouwborst 2010; de Oliveira et al. 2011). This was not unusual since, Czech and Krausman (1997), and Possingham et al. (2002), reiterated that it has been a common understanding that threatened plant species are aligned with either national or international conservation status. The recorded species belonged to 12 families, including Apocynaceae, Asparagaceae, Canellaceae, Dioscoreaceae, Fabaceae, Hyacinthaceae, Lauraceae, Ochnaceae, Proteaceae, Rosaceae, Zamiaceae, and Zingiberaceae. Family Lauraceae contains two tree species, whereas, other families are represented by a single species (Table 1).

Moreover, family Lauraceae was only noticed in The Vondo site, which forms part of the Afromontane forest in the Soutpansberg (Table 2). This was common and literary, since literature studies suggest that tree species seemed to be more abundant in forests (Slik et al. 2015; Sun et al. 2017), rather in any biome. The diversity of threatened plant families reaffirms the evidence that indeed the Soutpansberg Site of the Vhembe Biosphere Reserve in the Limpopo Province, South Africa is a biodiversity hotspot (Küper et al. 2004; Reyers 2004; Clark et al. 2011; Moraswi et al. 2019; Hahn 2019; Bamigboye and Tshisikhawe 2020). In spite that some vernacular names cited by the participants were firstly recorded in the current study, all the recorded threatened plant species have their Tshivenda names and this demonstrates their local values. In the Soutpansberg Region, usually, the vernacular names for the folk medicinal plant species used by the Vhavenda ethnic group are associated with the name the ailments that they treat (Personal communication with all the recruits). For example, the Tshivenda vernacular name of the species Ocotea bullata (Burch.) Baill., is called Mulafhadali, and it means the malaria healer, with the prefix "Mulafha-", meaning the healer in Tshivenda language and the suffix "-dali", meaning the malarial infection. Maroyi and Van der Maesen (2013), affirmed that the vernacular names of plant species, implies their usefulness, since folk people hardly name plant species that they do not utilize. 
Table 1. An inventory of threatened plant diversity in the Soutpansberg Site of the Vhembe Biosphere Reserve, Limpopo Province, South Africa

\begin{tabular}{|c|c|c|c|c|c|c|c|c|c|c|c|}
\hline Family & Botanical names and voucher number & $\begin{array}{l}\text { Vernacular } \\
\text { venda names }\end{array}$ & Habitus & $\begin{array}{l}\text { IUCN } \\
\text { Status } \\
(2019) \\
\end{array}$ & $\begin{array}{l}\text { SANBI } \\
\text { Status } \\
(2017)\end{array}$ & Socio- values & Parts used & $\begin{array}{l}\text { Same use } \\
\text { citations }\end{array}$ & $\mathbf{U V}$ & RFC & FL $(\%)$ \\
\hline Apocynaceae & Huernia nouhuysii I.Verd. (RAMLJ 021) & $\begin{array}{l}\text { Tshiditshinzhi-tsha- } \\
\text { Vhusendeka* }\end{array}$ & Succulent & - & VU & Birdlime-making & Latex & - & 0.250 & 0.019 & 1.970 \\
\hline Asparagaceae & $\begin{array}{l}\text { Asparagus sekukuniensis (Oberm.) } \\
\text { Fellingham \& N.L.Mey. (RAMLJ 013) }\end{array}$ & $\begin{array}{l}\text { Lufhaladzamakole } \\
\text { lwa thavha }\end{array}$ & Cactus & EN & EN & Medicinal & Whole plant & A & 0.077 & 0.064 & 6.404 \\
\hline Canellaceae & $\begin{array}{l}\text { Warburgia salutaris (G.Bertol.) Chiov. } \\
\text { (RAMLJ 014) }\end{array}$ & Mulanga & Tree & EN & EN & Medicinal & $\begin{array}{l}\text { Bark, leaves } \\
\text { and root }\end{array}$ & $\mathrm{B}_{1}, \mathrm{~B}_{2}, \mathrm{~B}_{3}$ & 0.0278 & 0.177 & 17.734 \\
\hline Dioscoreaceae & Dioscorea sylvatica Eckl. (RAMLJ 023) & Lurangatshiredzi* $^{*}$ & Climber & VU & VU & $\begin{array}{l}\text { Ethnoveterinary } \\
\text { medicine }\end{array}$ & Bulb tuber & - & 0.100 & 0.049 & 4.926 \\
\hline Fabaceae & $\begin{array}{l}\text { Rhynchosia vendae C.H.Stirt. (RAMLJ } \\
025 \text { ) }\end{array}$ & Musivhamato & Climber & - & VU & $\begin{array}{l}\text { Medicinal and } \\
\text { ornamentals }\end{array}$ & Whole plant & $\mathrm{C}$ & 0.167 & 0.059 & 5.911 \\
\hline Hyacinthaceae & $\begin{array}{l}\text { Bowiea volubilis Harv. ex Hook.f. subsp. } \\
\text { volubilis (RAMLJ 015) }\end{array}$ & Nyalakhobvu & Climber & - & VU & Medicinal & Whole plant & $\mathrm{D}$ & 0.077 & 0.064 & 6.404 \\
\hline Lauraceae & $\begin{array}{l}\text { Ocotea kenyensis (Chiov.) Robyns \& } \\
\text { R.Wilczek (RAMLJ 026) }\end{array}$ & Mulafhadali* & Tree & VU & VU & $\begin{array}{l}\text { Medicinal } \\
\text { and timber }\end{array}$ & $\begin{array}{l}\text { Bark, root } \\
\text { and the leaves }\end{array}$ & $\mathrm{E}$ & 0.067 & 0.059 & 5.911 \\
\hline Lauraceae & $\begin{array}{l}\text { Ocotea bullata (Burch.) Baill. (RAMLJ } \\
\text { 033) }\end{array}$ & Mulafhadali* & Tree & - & $\mathrm{EN}$ & Medicinal & Back and leaves & $\mathrm{F}_{1}, \mathrm{~F}_{2}$ & 0.063 & 0.079 & 7.882 \\
\hline Ochnaceae & $\begin{array}{l}\text { Brackenridgea zanguebarica Oliv. } \\
\text { (RAMLJ 027) }\end{array}$ & Mutavhatsindi & Tree & - & $\mathrm{CR}$ & Medicinal & Barks and root & $\mathrm{D}, \mathrm{G}_{1}, \mathrm{G}_{2}, \mathrm{G}_{3}$ & 0.024 & 0.202 & 20.197 \\
\hline Proteaceae & $\begin{array}{l}\text { Protea laetans L.E.Davidson (RAMLJ } \\
\text { 029) }\end{array}$ & Muphuphadzingu* & Shrub & VU & VU & Medicinal & Fruit and root & - & 0.091 & 0.053 & 5.419 \\
\hline Rosaceae & $\begin{array}{l}\text { Prunus africana (Hook.f.) Kalkman } \\
\text { (RAMLJ 031) }\end{array}$ & Mulalamaanga & Tree & - & VU & $\begin{array}{l}\text { Medicinal } \\
\text { and timber }\end{array}$ & Bark and stem & $\mathrm{D}$ & 0.182 & 0.053 & 5.419 \\
\hline Zamiaceae & $\begin{array}{l}\text { Encephalartos hirsutus P.J.H.Hurter } \\
\text { (RAMLJ 032) }\end{array}$ & Muvayambilana* & Cycad & - & $\mathrm{CR}$ & $\begin{array}{l}\text { Medicinal and } \\
\text { ornamentals }\end{array}$ & Whole plant & - & 0.200 & 0.049 & 4.926 \\
\hline Zingiberaceae & $\begin{array}{l}\text { Siphonochilus aethiopicus (Schweinf.) } \\
\text { B.L.Burtt (RAMLJ 030) }\end{array}$ & Dzhinzhadaka* & Herb & - & CR & $\begin{array}{l}\text { Medicinal and } \\
\text { ornamental }\end{array}$ & Whole plant & $\mathrm{H}_{1}, \mathrm{H}_{2}, \mathrm{H}_{3}$ & 0.143 & 0.069 & 6.897 \\
\hline
\end{tabular}


Table 2. Threatened plant species distribution, locations and observed threats across the Soutpansberg Region of the Vhembe Biosphere Reserve, Limpopo Province, South Africa

\begin{tabular}{|c|c|c|c|c|c|}
\hline \multirow{3}{*}{ Plant species } & \multicolumn{3}{|c|}{ Plant species location } & \multirow{3}{*}{$\begin{array}{l}\text { No. of observed } \\
\text { sites within the } \\
\text { studied region } \\
\end{array}$} & \multirow{3}{*}{ Observed threats } \\
\hline & \multirow{2}{*}{ Location } & \multicolumn{2}{|c|}{ Coordinates of location } & & \\
\hline & & Latitudes & Longitudes & & \\
\hline Asparagus sekukuniensis & Muruniwa & $22^{\circ} 58^{\prime} 59.052^{\prime \prime} \mathrm{S}$ & $30^{\circ} 10^{\prime} 28.477^{\prime \prime} \mathrm{E}$ & 1 & $\begin{array}{l}\text { Habitat transformation due to human- } \\
\text { settlement and recurring high-intensity fire } \\
\text { man-made fire }\end{array}$ \\
\hline $\begin{array}{l}\text { Bowiea volubilis subsp. } \\
\text { volubilis }\end{array}$ & $\begin{array}{l}\text { Mauluma; Tshitavha, } \\
\text { Matshavhawe and Vuvha }\end{array}$ & $\begin{array}{l}22^{\circ} 56^{\prime} 10.293^{\prime \prime} \mathrm{S} ; 22^{\circ} 57^{\prime} 57.953^{\prime \prime} \mathrm{S} \\
22^{\circ} 58^{\prime} 26.17^{\prime \prime} \mathrm{S} ; 22^{\circ} 59^{\prime} 34.0913^{\prime \prime} \mathrm{S}\end{array}$ & $\begin{array}{l}30^{\circ} 9^{\prime} 32.992^{\prime \prime} \mathrm{E} ; 30^{\circ} 11^{\prime} 27.225^{\prime \prime} \mathrm{E} \\
30^{\circ} 7^{\prime} 9.699^{\prime \prime} \mathrm{E} ; 30^{\circ} 10^{\prime} 59.016^{\prime \prime} \mathrm{E}\end{array}$ & 4 & $\begin{array}{l}\text { Over-harvesting, invasion by alien plant } \\
\text { species }\end{array}$ \\
\hline $\begin{array}{l}\text { Brackenridgea } \\
\text { zanguebarica }\end{array}$ & Thengwe & $22^{\circ} 40^{\prime} 22.325^{\prime \prime} \mathrm{S}$ & $30^{\circ} 34^{\prime} 22.659^{\prime \prime} \mathrm{E}$ & 1 & $\begin{array}{l}\text { Over-exploitation due high subsistence and } \\
\text { commercial demand }\end{array}$ \\
\hline Dioscorea sylvatica. & $\begin{array}{l}\text { Tshifhire, Muruniwa and } \\
\text { Tshamatangwana }\end{array}$ & $\begin{array}{l}23^{\circ} 0^{\prime} 19.901 " \mathrm{~S} ; 22^{\circ} 59^{\prime} 26.002^{\prime \prime} \mathrm{S} \\
22^{\circ} 58^{\prime} 19.423^{\prime \prime} \mathrm{S}\end{array}$ & $\begin{array}{l}30^{\circ} 7^{\prime} 52.852^{\prime \prime} \mathrm{E} ; 30^{\circ} 9^{\prime} 24.623^{\prime \prime} \mathrm{E} \\
30^{\circ} 18^{\prime} 23.864^{\prime \prime} \mathrm{E}\end{array}$ & 3 & $\begin{array}{l}\text { Habitat transformation due to new human- } \\
\text { settlement development, invasion by alien plant } \\
\text { species and over-harvesting }\end{array}$ \\
\hline Encephalartos hirsutus & $\begin{array}{l}\text { Muruniwa and Vondo la } \\
\text { Thavha }\end{array}$ & $22^{\circ} 59^{\prime} 46.154^{\prime \prime} \mathrm{S} ; 22^{\circ} 56^{\prime} 14.813^{\prime \prime} \mathrm{S}$ & $30^{\circ} 9^{\prime 25.974 " ~ E ; ~} 30^{\circ} 21^{\prime} 8.15^{\prime \prime} \mathrm{E}$ & 2 & $\begin{array}{l}\text { Over-exploitation due to high commercial } \\
\text { demand at both local and international markets }\end{array}$ \\
\hline Huernia nouhuysii & DoliDoli & $22^{\circ} 42^{\prime} 15.742^{\prime \prime} \mathrm{S}$ & $30^{\circ} 10^{\prime} 26.554^{\prime \prime} \mathrm{E}$ & 1 & $\begin{array}{l}\text { Recurring drought, invasion by alien plant } \\
\text { species and habitat transformation due to new } \\
\text { human-settlement development }\end{array}$ \\
\hline Ocotea bullata & $\begin{array}{l}\text { Tshanowa Mountain, } \\
\text { Thathe Vondo }\end{array}$ & $22^{\circ} 56^{\prime} 18.719^{\prime \prime} \mathrm{S}$ & $30^{\circ} 21^{\prime} 8.373^{\prime \prime} \mathrm{E}$ & 1 & Habitat fragmentation due to pine plantation \\
\hline Ocotea kenyensis & $\begin{array}{l}\text { Thethe Vondo Holy forest, } \\
\text { and Tshamatingwane }\end{array}$ & $22^{\circ} 53^{\prime} 6.374^{\prime \prime} \mathrm{S} ; 22^{\circ} 58^{\prime} 19.844^{\prime \prime} \mathrm{S}$ & $30^{\circ} 18^{\prime} 41.363^{\prime \prime} \mathrm{E} ; 30^{\circ} 18^{\prime} 15.879^{\prime \prime} \mathrm{E}$ & 2 & Habitat fragmentation due to pine plantation \\
\hline Protea laetans & $\begin{array}{l}\text { Muruniwa Mutshedzi and } \\
\text { Muruniwa Maramboni }\end{array}$ & $22^{\circ} 58^{\prime} 14.937^{\prime \prime} \mathrm{S} ; 22^{\circ} 59^{\prime} 13.65^{\prime \prime} \mathrm{S}$ & $30^{\circ} 18^{\prime} 20.503^{\prime \prime} \mathrm{E} ; 30^{\circ} 8^{\prime} 59.46^{\prime \prime} \mathrm{E}$ & 2 & $\begin{array}{l}\text { Habitat transformation due to new human- } \\
\text { settlement development, recurring high } \\
\text { intensity man-made fire }\end{array}$ \\
\hline Prunus africana & $\begin{array}{l}\text { Khalavha, Tshitangani site } \\
\text { and Thathe Vondo, } \\
\text { Tshanowa Mountain Valley }\end{array}$ & $22^{\circ} 55^{\prime} 5.956^{\prime \prime} \mathrm{S} ; 22^{\circ} 55^{\prime} 32.456^{\prime \prime} \mathrm{S}$ & $30^{\circ} 18^{\prime} 24.894^{\prime \prime} \mathrm{E} ; 30^{\circ} 20^{\prime} 46.883^{\prime \prime E}$ & 2 & Habitat fragmentation due to pine plantation \\
\hline Rhynchosia vendae & Makonde and Ha-Maelula & $22^{\circ} 47^{\prime} 19.536^{\prime \prime} \mathrm{S} ; 22^{\circ} 59^{\prime} 9.146^{\prime \prime} \mathrm{S}$ & $30^{\circ} 33^{\prime} 47.509^{\prime \prime} \mathrm{E} ; 30^{\circ} 8^{\prime} 51.234^{\prime \prime} \mathrm{E}$ & 2 & $\begin{array}{l}\text { Invasion by alien plant species and habitat } \\
\text { transformation due to new human-settlement } \\
\text { development }\end{array}$ \\
\hline Siphonochilus aethiopicus & $\begin{array}{l}\text { Thathe Vondo, } \\
\text { Tshamatingwane }\end{array}$ & $22^{\circ} 58^{\prime} 11.676^{\prime \prime} \mathrm{S}$ & $30^{\circ} 18^{\prime} 17.197 " \mathrm{E}$ & 1 & Over-exploitation \\
\hline Warburgia salutaris & Ha-Matsa & $22^{\circ} 50^{\prime} 36.922^{\prime \prime} \mathrm{S}$ & $29^{\circ} 59^{\prime} 50.107^{\prime \prime} \mathrm{E}$ & 1 & $\begin{array}{l}\text { Over-exploitation due to commercial demand } \\
\text { in local market }\end{array}$ \\
\hline
\end{tabular}




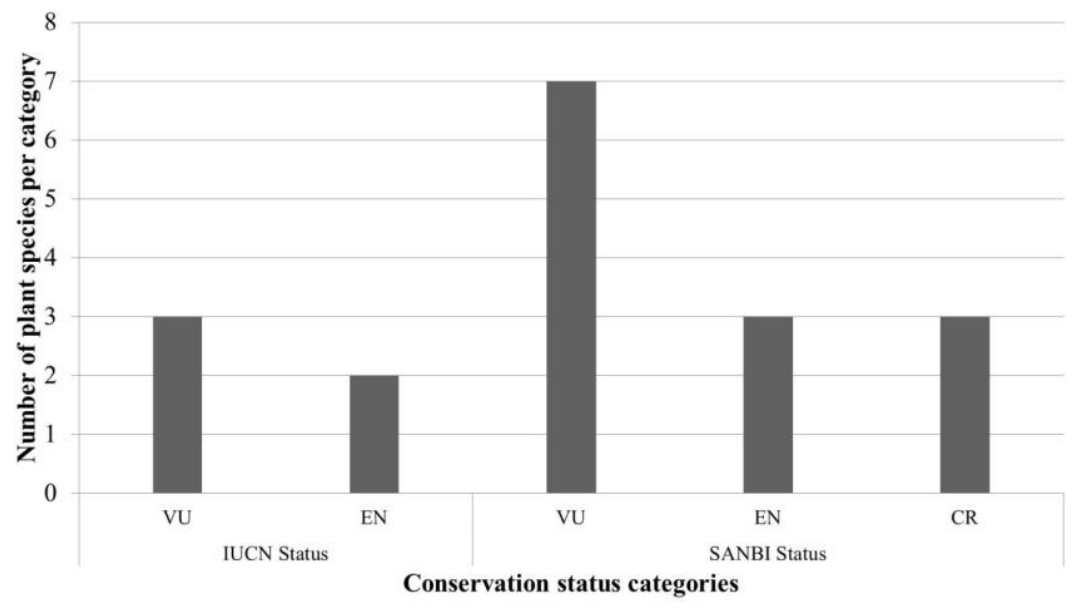

Figure 3. The number of international and national Red Listed threatened plant diversity

The frequently cited useful threatened plant species with $\mathrm{UV}>0.024$, RFC $>0.059$ and FL $>5.911 \%$ included A. sekukuniensis, $B$. volubilis subsp. volubilis, $B$. zanguebarica, O. bullata, $R$. vendae, S. aethiopicus, and $W$. salutaris (Table 1). The UV, of threatened plant species, was pivotal for evaluating the most useful species as compared to their counterparts in the same sample (Umair et al. 2017; Setshego et al. 2020). The RFC is the summation of the threatened plants' reported uses based on participants citations for certain species without considering the use categories (Kankara et al. 2015; Mwinga et al. 2019). The FL value is used for evaluating the level of significance of the useful threatened plant species within the studied region shows the proportion between the number of participants who claimed the use of threatened plants for similar significant purpose and all participants who cited those plants for any other purpose (Khan et al. 2014; Tuttolomondo et al. 2014; Kayani et al. 2015; Dembélé et al. 2015).

Moreover, the aforementioned ethnobotanical induces (UV, RFL and FL) were strategically used for identifying the most significant and useful threatened plant species within the studied region (Farooq 2019; Atyosi et al 2019). Despite the availability of good and well-established regulations to help preserve, protect and restrict utilization of threatened plant species in South Africa (Foden 2007), $W$. salutaris and $B$. zanguebarica seemed to be frequently utilized by local people within the studied region and their FL values range from $17.734 \%$ to $20.197 \%$. The results in current study illustrated local people utilizing W. salutaris and B. zanguebarica for none, but medicinal purposes only (Table 1). Although, this study lacks phytochemical and pharmacological evaluations, Mothupi (2014) and Ramarumo et al. (2019c), reiterated that African people in poor and marginalized communities usually utilized herbal medicines due to their therapeutic efficacy, viability, and reliability. Kurande et al. (2013), considered utilization and administration of herbal medicines in aboriginal cultural communities as completely experimental, whereas, Tengö et al. (2014), reported that traditional healing mechanisms required no validation of its phytochemical constituents, since it is trustworthy and it has been validated long-time ago through trial-error-experiments. Moreover, this study is, therefore, argued that high FL (\%) value of $W$. salutaris and $B$. zanguebarica delineates that folk knowledge associated with those species is common and well-known to the majority of dwellers within the studied region. Literary to the study done by Tshisikhawe et al. (2013), over-harvesting of such an important plant species could eventually lead to the deterioration of their population structure and conservation status. According to Schatz (2009), a decline in the number of useful threatened plant species could also negatively impact the livelihood chain and the provision of traditional health care in rural and marginalized communities.

Local people within the studied region were found utilizing various threatened plant species for various purposes, depending on their growth habits and partly used (Figure 4). This includes utilizing those species for medicinal purposes $(46.0 \%)$, medicinal and ornamentals $(23.0 \%)$, medicinal and timber $(15.0 \%)$, ethnoveterinary medicine $(8.0 \%)$, birdlime-making and ornamentals both constitute (8.0\%) (Figure 4A). Gosling et al. (2017) and Magwede et al. (2019) elucidated that local people in the Southern African Region, utilizes various plant resources for their various livelihood needs (Michler et al. 2019). Tree $(38.0 \%)$ and climbers (23.0) seemed to be the most preferred habitus, whereas, frequently utilized parts were whole plant $(38.0 \%)$, followed by the combination of bark, leaves, and root $(15.0 \%)$ (Figure $4 \mathrm{~B}$ and C). This was not unusual, since the study done by Leshabana and Tshisikhawe (2017) reaffirmed trees as the most preferred utilized plant habit. It is worth indicating that local people in the Soutpansberg Site of the Vhembe Biosphere Reserve in the Limpopo Province, South Africa have adopted their own and diverse livelihood strategies that include, frequent utilization of plant forms that have multi-useable parts and long life span (Sekgobela BF 2019, pers. com.; Siobo ZJ 
2019, pers. com.; Muthivhithi KD 2019, pers. com.). According to Kunwar et al. (2010), local people in rural and marginalized remote communities usually develop various livelihood strategies that suit their needs. Therefore, the frequent utilization of tree species within the studied region was influenced due to their multiple usages and long life span. Although the results of the present study seemed to be in accordance with other studies in the region (Rampedi and Olivier 2013; Muhali 2017; Tshisikhawe and Malunga 2017; Ndhlovu et al. 2019), it is worthy to argue that over-harvesting of threatened plant species could cause a decline in their population size and eventually rapid extinction.

\section{Distribution and population}

More than $53.0 \%$ of the recorded useful threatened plant species are likely distributed in one location across the studied region. Although SANBI, an affiliate to IUCN considered the vegetation status of the Thathe Vondo as vulnerable (Munyati and Sinthumule 2014) with some little patches of pristine ecosystems within, the results in the present study delineate that about $47.0 \%$ of the recorded useful threatened plant species were distributed in the remote areas of the Thathe Vondo and its surroundings. This was due to the fact that threatened plants are considered sensitive to climate change, and therefore, remote and high elevation areas create a suitable micro- climate for their survival (Telwala et al. 2013). Since more threatened plant taxon was recorded in high elevation areas, the present study argued that threatened plant species richness in the Soutansberg Site of the Vhembe Biosphere Reserve in the Limpopo Province, South Africa, increased with an increase in elevation, annual rainfall and habitat viability. This was endorsed by both local and international scholars (Lobo et al. 2001; Vetaas and Grytnes 2002; Bruun et al. 2006; Munyati and Sinthumule 2014). The coordinates of locations for all the recorded useful threatened plant species range between $22^{\circ} 40^{\prime} 22.325^{\prime \prime}$ to $23^{\circ} 0^{\prime} 42.505^{\prime \prime}$ South latitudes and $29^{\circ} 59^{\prime} 50.107^{\prime \prime}$ to 30³3'47.509" East longitudes (Table 2). This can strengthen future monitoring of threatened plant species in the region. Whittaker et al. (2005) uttered that spatial information, including the use of GPS coordinates play an important role in modern conservation and monitoring. Table 2 shows that threatened plant species within the studied region are mostly threatened due to various threats regimes, including, habitat transformation, habitat fragmentation, over-harvesting, and invasion. Literature studies reaffirmed that invasion, over-exploitation of botanical resources, agricultural expansion, and habitat transformation are major cause of extinction risk (Du Toit et al. 2016; Heinrichs et al. 2016; Boon et al. 2016; Leroux et al. 2017; De Kort et al. 2018).

\section{Utilization modes}

\begin{tabular}{|c|c|}
\hline Medicinal & Medicinal \& ornamentals \\
\hline $\begin{array}{l}\text { Medicinal \& timber } \\
\text { Birdlime-making }\end{array}$ & Ethnoveterinary medicine \\
\hline
\end{tabular}

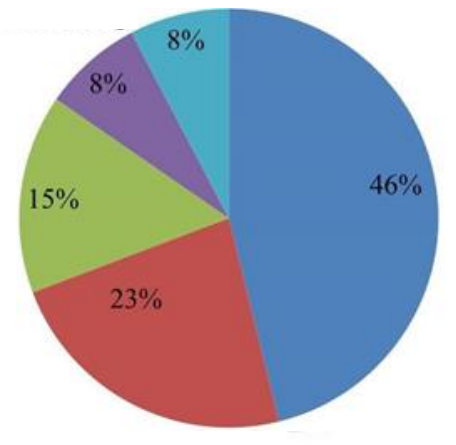

A

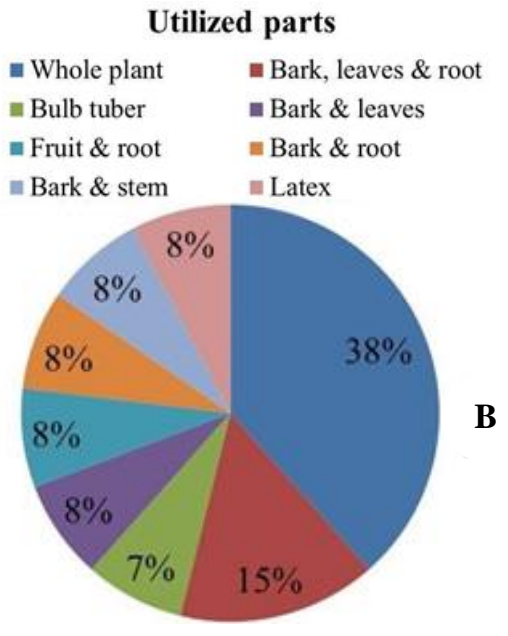

Utilized plant forms

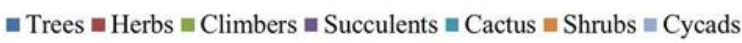

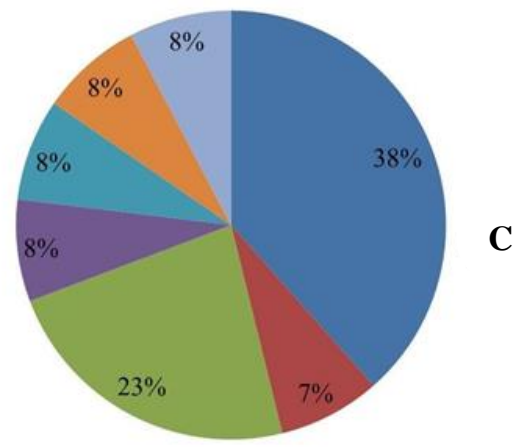

Figure 4. Utilization of threatened plant diversity 


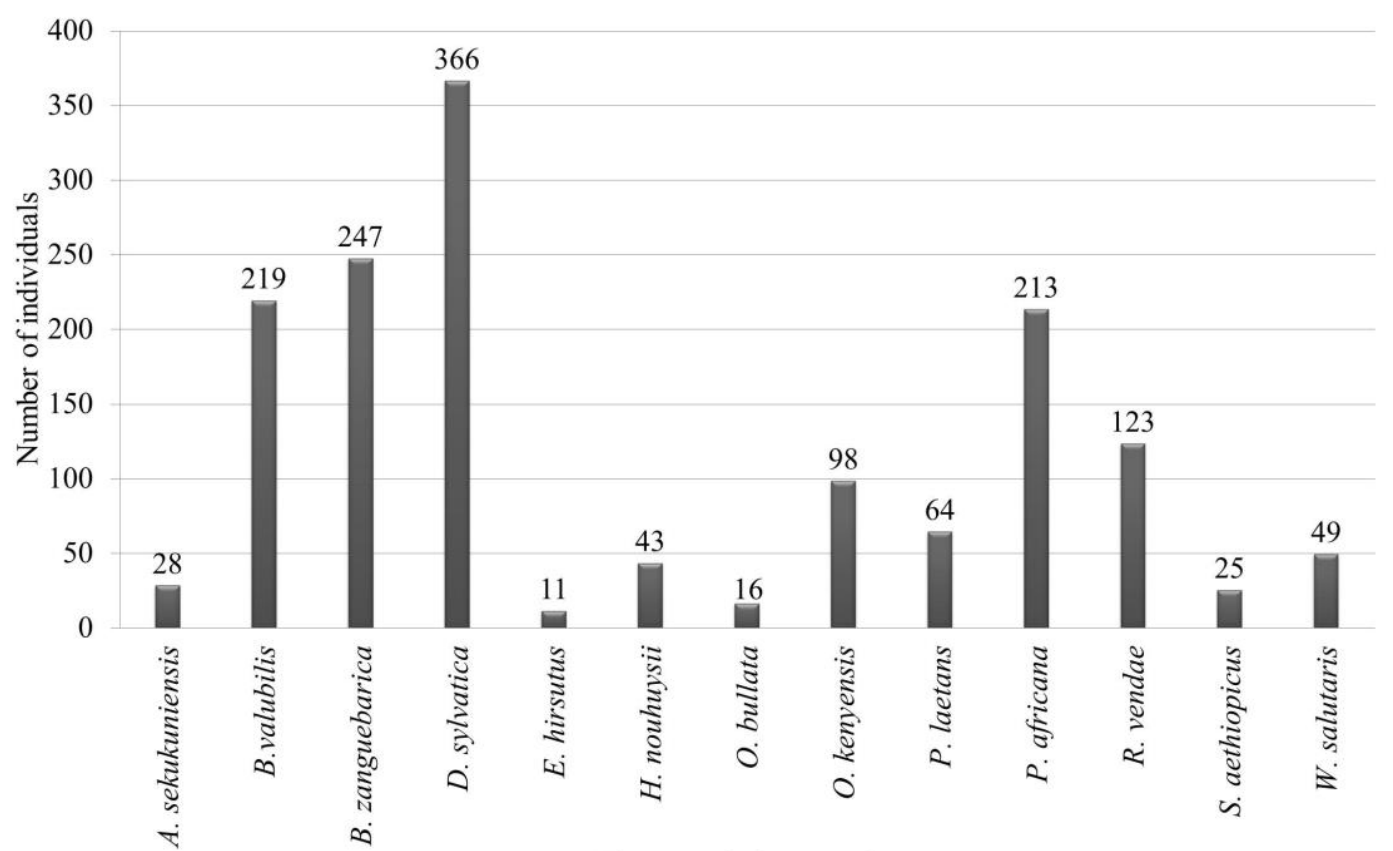

Threatened plant species

Figure 5. Number of adults threatened plants individuals within the studied region

Data about the population size of adult threatened plant species is considered crucial for either upgrading or downgrading the conservation status of the species, using version 3.1 of the IUCN 's Red List Categories and Criteria (IUCN 2012; Williams et al. 2013). Although the population size of adult $D$. sylvatica seemed to be over 300 individuals with various distributional ranges as compared to its counterparts (Figure 5 and Table 2), it still remains vulnerable to extinction since its combined area of occupancy within the studied region is approximately < $500 \mathrm{~m}^{2}$. Presently the distribution range of $D$. sylvatica in the studied region is restricted to three small remote areas called Tshifhire, Muruniwa, and Tshamatangwana (Table 2 ). Although the conservation status of this species is only recognized nationally (Figure 3 and Table 1), the Categories and Criteria of the IUCN's Red List suggests that small distribution range, area of occupancy and other ecological aspects, implies that the species is on the verge of extinction risk (IUCN 2012). The results of this study showed threatened plant species with a population size < 100 adult individuals constituting an overall of $61.54 \%$ (Figure 5). Among them, there were, P. laetans, $O$. kenyensis, O. bullata, A. sekukuniensis. W. salutaris, $H$. nouhuysii, E. hirsutus and S. aethiopicus (Figure 5). This study argued that the smaller the population size of individuals of threatened plants in a single area of occupancy, the more vulnerable towards the verge of extinction they become. Brackenridgea zanguebarica is considered Critical Endangered in South Africa and its distribution range is restricted to a single geographic area or area of occupancy called Thengwe (Tiawoun et al. 2019).
The current study provides substantial information about useful threatened plant species, their distribution range and values linked to the improvement of local livelihoods and development. Detailed information about threatened plant species remains fundamental for making informed decisions that are important for managing species of conservation concern. In the Vhembe Biosphere Reserve, Limpopo Province, South Africa, local people do not perceive the values derived from threatened plant species as separate from their desire to improve their own livelihoods and daily strive for civilization. Therefore, the present study argued that insights about the dynamics surrounding threatened plant species in context with their utilization, population size, distribution range, and conservation status, are fundamental to encourage speciesspecificity monitoring and management plans. To the best of our knowledge, no study of this nature has been done before in the Vhembe Biosphere Reserve, Limpopo Province, South Africa. In spite of all the restrictions that prohibit the use of threatened plant species in South Africa, local people in the studied areas perceived subsistence utilization of such plants as an integral part of their inherent heritage. This study has significantly demonstrated utilization of threatened plant species in the Vhembe Biosphere Reserve, Limpopo Province, South Africa. Although the utilization of threatened plant species seemed to be pivotal for the improvement of local livelihoods in the region, this study, therefore, recommended the reevaluation of the conservation status of highly utilized species within the studied region. 


\section{ACKNOWLEDGEMENTS}

This work was partially sponsored through the National Research Foundation of South Africa (NRF Grant no. 112976) and the Govan Mbeki Research and Development Centre (GMRDC), University of Fort Hare. The study site map and transportation during data gathering were sponsored by Mielelani (Pty) Limited and GreenEmpire (Pty) Limited. The authors would like to direct their gratitude to all the recruits who took part in the current study for their holistically sharing of their knowledge.

\section{REFERENCES}

Ahmed N, Mahmood A, Tahir SS, Bano A, Malik RN, Hassan S, Ashraf A. 2014. Ethnomedicinal knowledge and relative importance of indigenous medicinal plants of Cholistan desert, Punjab Province, Pakistan. J Ethnopharmacol 155: 1263-1275.

Al-Qur'an S. 2009. Ethnopharmacological survey of wild medicinal plants in Showbak, Jordan. J Ethnopharmacol 123: 45-50.

Andrade-Cetto A Heinrich M. 2011. From the field into the lab: usefur approaches to selecting species based on local knowledge. Front Pharmacol 2: 20 .

Atyosi Z, Ramarumo LJ, Maroyi A. 2019. Alien Plants in the Eastern Cape Province in South Africa: Perceptions of Their Contributions to Livelihoods of Local Communities. Sustain 11: 5043.

Badenhorst AB. 2011. An investigation into the compliance of selected nurseries and garden centres within Kwazulu-Natal Ethekwini and the Umsunduzi geographical regions, with the Conservation of Agricultural Resources Act 1983 (Act no. 43 of 1983) Cara and the National Environmental Management: Biodiversity Act 2004 (Act no. 10 of 2004) Nemba. [Masters Dissertation]. University of South Africa, Gauteng Province, South Africa.

Bailey KM, McCleery RA, Binford MW, Zweig C. 2016. Land-cover change within and around protected areas in a biodiversity hotspot. $J$ Land Use Sci 11: 154-176.

Bamigboye S, Tshisikhawe MP. 2020. The impacts of bark harvesting on a population of Encephalartos transvenosus (Limpopo cycad), in Limpopo Province, South Africa. Biodiversitas 21: 8-13.

Bamigboye SO, Tshisikhawe MP, Taylor JP. 2017. Detecting threats to Encephalartos transvenosus (Limpopo cycad) in Limpopo Province, South Africa through indigenous knowledge. Indian J Tradit Knowl 16: 251-255.

Barton JM, Klemd R, Zeh A. 2006. The Limpopo belt: A result of Archean to 348 Proterozoic, Turkic-type orogenesis? Spec Pap-Geol Soc Am 405: 315-332.

Bellard C, Cassey P, Blackburn TM. 2016. Alien species as a driver of recent extinctions. Biol Lett 12: 20150623.

Biró É, Babai D, Bódis J, Molnár Z. 2014. Lack of knowledge or loss of knowledge? Traditional ecological knowledge of population dynamics of threatened plant species in East-Central Europe. J Nat Conserv 22: 318-325

Boon R, Cockburn J, Douwes E, Govender N, Ground L, Mclean C, Roberts D, Rouget M, Slotow R. 2016. Managing a threatened savanna ecosystem (KwaZulu-Natal Sandstone Sourveld) in an urban biodiversity hotspot: Durban, South Africa. Bothalia-Afri Biol Conserv 46: 1-12.

Brose U, Blanchard JL, Eklöf A, Galiana N, Hartvig MR. Hirt M, Kalinkat G, Nordström MC, O'Gorman EJ, Rall BC, Schneider FD. 2017. Predicting the consequences of species loss using size-structured biodiversity approaches. Biol Rev 92: 684-697.

Bruun HH, Moen J, Virtanen R, Grytnes JA, Oksanen L, Angerbjörn A. 2006. Effects of altitude and topography on species richness of vascular plants, bryophytes and lichens in alpine communities. J Veg Sci 17: 37-46.

Buck M, Hamilton C. 2011. The Nagoya Protocol on access to genetic resources and the fair and equitable sharing of benefits arising from their utilization to the Convention on Biological Diversity. Rev Euro Commun Int Environ Law 20: 47-61.
Ceballos G, Ehrlich PR, Dirzo R. 2017. Biological annihilation via the ongoing sixth mass extinction signaled by vertebrate population losses and declines. Proc Nat Acad Sci 114: E6089-E6096.

Census. 2011. District Municipality 934 from Census 2011. Available online: https: //census2011.adrianfrith.com/place/934 (Accessed on 29 October 2019).

Chambers R. 1994. Participatory rural appraisal (PRA): Analysis of experience. World Dev 22: 1253-1268.

Clark VR, Barker NP, Mucina L. 2011. The Great Escarpment of southern Africa: a new frontier for biodiversity exploration. Biol Conserv 20: 2543

Cock MJ, van Lenteren JC, Brodeur J, Barratt BI, Bigler F, Bolckmans K, Cônsoli FL, Haas F, Mason PG, Parra JR. 2010. Do new access and benefit-sharing procedures under the convention on biological diversity threaten the future of biological control?. Bio Cont 55: 199218.

Constant NL, Tshisikhawe MP. 2018. Hierarchies of knowledge: ethnobotanical knowledge, practices and beliefs of the Vhavenda in South Africa for biodiversity conservation. J Ethnobiol Ethnomed 14: 56.

Cousins JA, Sadler JP, Evans J. 2010. The challenge of regulating private wildlife ranches for conservation in South Africa. Ecol Soc 15: 28.

Crouch NR, Douwes E, Wolfson MM, Smith GF, Edwards TJ. 2008. South Africa's bioprospecting, access and benefit-sharing legislation: current realities, future complications, and a proposed alternative. $\mathrm{S}$ Afr J Sci 104: 355-366.

Czech B, Krausman PR. 1997. Distribution and causation of species endangerment in the United States. Sci 277: 1116-1117.

De Kort H, Prunier JG, Tessier M, Turlure C, Baguette M, Stevens VM. 2018. Interacting grassland species under threat of multiple global change drivers. J Biol 45: 2133-2145.

de Oliveira JP, Balaban O, Doll CN, Moreno-Peñaranda R, Gasparatos A, Iossifova D, Suwa A. 2011. Cities and biodiversity: Perspectives and governance challenges for implementing the convention on biological diversity (CBD) at the city level. Biol Conserv 144: 1302-1313.

De Vos JM, Joppa LN, Gittleman JL, Stephens PR, Pimm SL. 2015. Estimating the normal background rate of species extinction. Conserv Biol 29: 452-462.

Dembélé U, Lykke AM, Koné Y, Témé B, Kouyaté AM. 2015. Use-value and importance of socio-cultural knowledge on Carapa procera trees in the Sudanian zone in Mali. J Ethnobiol Ethnomed 11: 14. DOI: 10.1186/1746-4269-11-14.

Department of Trade and Industry. 2017. Special Economic Zone Advisory Board: An Annual Report 2017/ 2018. Available online: http:

//www.thedti.gov.za/industrial_development/docs/SEZ_Annual_Repo rt.pdf [1 November 2019]

Dludlu MN, Dlamini PS, Sibandze GF, Vilane VS, Dlamini CS. 2017. Distribution and conservation status of the endangered pepper bark tree Warburgia salutaris (Canellaceae) in Swaziland. Oryx 51: 451454.

Du Toit MJ, Kotze DJ, Cilliers SS. 2016. Landscape history, time lags and drivers of change: urban natural grassland remnants in Potchefstroom, South Africa. Landscape Ecol 31: 2133-2150.

Dzerefos CM, Witkowski ET, Kremer-Köhne S. 2017. Aiming for the biodiversity target with the social welfare arrow: medicinal and other useful plants from a Critically Endangered grassland ecosystem in Limpopo Province, South Africa. Int J Sustain Dev World Ecol 24: 52-64.

Farooq M. 2019. Pioneer community level syntaxonomy of forests of lesser Himalayan belt of upper Tanawal Mansehra, Pakistan. Proc Int Acad Ecol Environ Sci 9: 127-136.

Flax VL, Hamela G, Mofolo I, Hosseinipour MC, Hoffman IF, Maman S. 2017. Factors influencing postnatal Option B+ participation and breastfeeding duration among HIV-positive women in Lilongwe District, Malawi: A qualitative study. PLoS One 12: e0175590.

Foden W. 2007. South Africa's threatened species legislation: What stands between our plants and extinction?. S Afri J Bot 73: 288-288.

Fouche G, Van Rooyen S, Faleschini T. 2013. Siphonochilus aethiopicus, a traditional remedy for the treatment of allergic asthma. Intl $\mathrm{J}$ Genuine Tradit Med 3: e6. http: //www.e-tang.org/

Gosling A, Shackleton CM, Gambiza J. 2017. Community-based natural resource use and management of Bigodi Wetland Sanctuary, Uganda, for livelihood benefits. Wet Ecol Manag 25: 717-730. 
Graham RW, Belmecheri S, Choy K, Culleton BJ, Davies LJ, Froese D, Heintzman PD, Hritz C, Kapp JD, Newsom LA, Rawcliffe R. 2016 Timing and causes of mid-Holocene mammoth extinction on St. Paul Island, Alaska. Proc Nat Acad Sci USA 113: 9310-9314.

Hahn N. 2011. Refinement of the Soutpansberg Geomorphic Province, Limpopo, South Africa. Trans Royal Soc S Afr 66: 32-40.

Hahn N. 2017. Endemic flora of the Soutpansberg, Blouberg and Makgabeng. S Afri J Bot 113: 324-336.

Hahn N. 2018. An historic account of the extinct high rainfall grasslands of the Soutpansberg, South Africa. Trans Soc S Afr 73: 20-32.

Hahn N. 2019. Indigenous vascular plants of the Soutpansberg, South Africa. Bothalia-Afri Bio Conserv 49: 1-5.

Heinrichs JA, Bender DJ, Schumaker NH. 2016. Habitat degradation and loss as key drivers of regional population extinction. Ecol Model 335: 64-73.

Heywood VH. 2015. In situ conservation of plant species-an unattainable goal?. Israel J Plant Sci 63: 211-231.

Hussain W, Ullah M, Dastagir G, Badshah LA. 2018. Quantitative ethnobotanical appraisal of medicinal plants used by inhabitants of lower Kurram, Kurram agency, Pakistan. Avicenna J Phytomed 8: 313-329.

IUCN. 2012. IUCN Red List Categories and Criteria: Version 3.1. Second edition. IUCN, Gland, Switzerland and Cambridge, UK.

Jimu L, Ngoroyemoto N, Mujuru L. 2013. Structural diversity and regeneration of the endangered Prunus africana (Rosaceae) in Zimbabwe. Afr J Ecol 51: 102-110.

Kankara SS, Ibrahim MH, Mustafa M, Go R. 2015. Ethnobotanical survey of medicinal plants used for traditional maternal healthcare in Katsina state, Nigeria. S Afri J Bot 97: 165-175.

Kayani S, Ahmad M, Sultana S, Shinwari ZK, Zafar M, Yaseen G, Hussain M, Bibi T. 2015. Ethnobotany of medicinal plants among the communities of Alpine and Sub-alpine regions of Pakistan. J Ethnopharmacol 164: 186-202.

Keith DA, Akçakaya HR, Thuiller W, Midgley GF, Pearson RG, Phillips SJ, Regan HM, Araújo MB, Rebelo TG. 2008. Predicting extinction risks under climate change: coupling stochastic population models with dynamic bioclimatic habitat models. Biol Lett 4: 560-563.

Khan I, AbdElsalam NM, Fouad H, Tariq A, Ullah R, Adnan M. 2014 Application of ethnobotanical indices on the use of traditional medicines against common diseases. Evid Based Compl Alt Med 2014: 1-21.

Kirchhof S, Krämer M, Linden J, Richter K. 2010. The reptile species assemblage of the Soutpansberg (Limpopo Province, South Africa) and its characteristics. Salamandra 46: 147-166.

Kunene EN, Masarirambi MT. 2018. Role of biotechnology in the conservation of rare, threatened and endangered medicinal plant species in the Kingdom of Eswatini (Swaziland). Adv Med Plant Res 6: 26-32.

Kunwar RM, Fadiman M, Thapa S, Acharya RP, Cameron M, Bussmann RW. 2010. Plant use values and phytosociological indicators: Implications for conservation in the Kailash Sacred Landscape, Nepal. Ecol Indica 108: 105679.

Küper W, Sommer JH, Lovett JC, Mutke J, Linder HP, Beentje HJ, Van Rompaey RS, Chatelain C, Sosef M, Barthlott W. 2004. Africa's hotspots of biodiversity redefined. Ann Missouri Bot Gard 9: 525 535 .

Kurande VH, Waagepetersen R, Toft E, Prasad R. 2013. Prasad, R. Reliability studies of diagnostic methods in Indian traditional Ayurveda medicine: an overview. J Ayurveda Intl Med 4: 67-76.

Leitao RP, Zuanon J, Villéger S, Williams SE, Baraloto C, Fortunel C, Mendonça FP, Mouillot D. 2016. Rare species contribute disproportionately to the functional structure of species assemblages. Proc Royal Soc Biol Sci 283: 20160084.

Lenzen M, Moran D, Kanemoto K, Foran B, Lobefaro L, Geschke A 2012. International trade drives biodiversity threats in developing nations. Nature 486: 109-112.

Leroux SJ, Albert CH, Lafuite AS, Rayfield B, Wang S, Gravel D. 2017. Structural uncertainty in models projecting the consequences of habitat loss and fragmentation on biodiversity. Ecog 40: 36-47.

Leshabana O, Tshisikhawe MP. 2019. An Investigation of Firewood Species used by Community of Gundani Village in Vhembe District, Limpopo Province, South Africa. Indian J Ecol 46: 921-925.

Lobo JM, Castro I, Moreno JC. 2001. Spatial and environmental determinants of vascular plant species richness distribution in the Iberian Peninsula and Balearic Islands. Biol J Linn Soc 73: 233-253.
Luseba D, Tshisikhawe M.P. 2013. Medicinal plants used in the treatment of livestock diseases in Vhembe region, Limpopo Province, South Africa. J Med Plants Res 7: 593-601.

Ma Y, Chen G, Grumbine RE, Dao Z, Sun W, Guo H. 2013. Conserving plant species with extremely small populations (PSESP) in China. Biol Conserv 22: 803-809.

Magwede K, Van Wyk BE, Van Wyk AE. 2019. An inventory of Vhavenda useful plants. S Afri J Bot 122: 57-89.

Manne LL, Pimm SL. 2001. Beyond eight forms of rarity: which species are threatened and which will be next?. Anim Conserv 4: 221-229.

Maroyi A, Van der Maesen LJG. 2013. Gloriosa superba L.(Colchicaceae): Ethnobotany and economic importance. Scr Bot Belg 50: 408-416.

Maroyi A. 2014. The genus Warburgia: A review of its traditional uses and pharmacology. Pharm Biol 52: 378-391.

Messer KD. 2010. Protecting endangered species: When are shoot-onsight policies the only viable option to stop poaching?. Ecol Econ 69: 2334-2340.

Michler LM, Treydte AC, Hayat H, Lemke S. 2019. Marginalised herders: Social dynamics and natural resource use in the fragile environment of the Richtersveld National Park, South Africa. Environ Dev 29: 2943.

Molewa BEE. 2007. National Environmental Management: Biodiversity Act, 2004: Act 10 of 2004. Threatened or protected marine species regulations. S Afr Govern Gazette 623: 40876.

Moraswi I, Bamigboye SO, Tshisikhawe MP, 2019. Conservation status and threats to vascular plant species endemic to Soutpansberg Mountain range in Limpopo Province, South Africa. Intl J Plant Biol 10: 7978 .

Mostert TH, Bredenkamp GJ, Klopper HL, Verwey C, Mostert RE, Hahn N. 2008. Major vegetation types of the Soutpansberg conservancy and the Blouberg nature reserve, South Africa. Koedoe 50: 32-48.

Mothupi MC. 2014. Use of herbal medicine during pregnancy among women with access to public healthcare in Nairobi, Kenya: a crosssectional survey. BMC Compl Alt Med 14: 432. DOI: 10.1186/14726882-14-432.

Mpandeli S. 2014. Managing climate risks using seasonal climate forecast information in Vhembe District in Limpopo Province, South Africa. J Sustain Dev 7: 68-81.

Muhali MD. 2017. Environmental resource utilization: A case study of traditional useful wild plant species in the Makhado Local Municipality. [Masters Dissertation]. University of Johannesburg, Gauteng Province, South Africa.

Munyati C, Sinthumule NI. 2014. Cover gradients and the forestcommunity frontier: Indigenous forests under communal management at Vondo and Xanthia, South Africa. J Sustain forest 33: 757-775.

Mwinga JL, Makhaga NS, Aremu AO, Otang-Mbeng W. 2019. Botanicals used for cosmetic purposes by Xhosa women in the Eastern Cape, South Africa. S Afr J Bot 126: 4-10.

Ndhlovu PT, Mooki O, Mbeng WO, Aremu AO. 2019. Plant species used for cosmetic and cosmeceutical purposes by the Vhavenda women in Vhembe District Municipality, Limpopo, South Africa. S Afr J Bot 122: 422-431.

Ngubeni N, Jacobs S, Seydack A, Vermeulen W, Sass G, Seifert T. 2017. Trade-off relationships between tree growth and defense: a comparison of Ocotea bullata and Curtisia dentata following bark harvesting in an evergreen moist South African Forest. Trees 31: 339348.

Ogundajo AL, Adeniran LA, Ashafa AO. 2018. Medicinal properties of Ocotea bullata stem bark extracts: phytochemical constituents, antioxidant and anti-inflammatory activity, cytotoxicity and inhibition of carbohydrate-metabolizing enzymes. J Int Med 16: 132-140.

Phumthum M, Srithi K, Inta A, Junsongduang A, Tangjitman K, Pongamornkul W, Trisonthi C, Balslev H. 2018. Junsongduang, A.; Tangjitman, K.; Pongamornkul, W.; Trisonthi, C.; Balslev, H. Ethnomedicinal plant diversity in Thailand. J Ethnopharmacol 214: 90-98.

Pimm SL, Jenkins CN, Abell R, Brooks TM, Gittleman JL, Joppa LN, Raven PH, Roberts CM, Sexton JO. 2014. The biodiversity of species and their rates of extinction, distribution, and protection. Science 344 : 1246752.

Pimm SL, Joppa LN. 2015. How many plant species are there, where are they, and at what rate are they going extinct?. Ann Mo Bot Gard 100: 170-177. 
Possingham HP, Andelman SJ, Burgman MA, Medellín RA, Master LL, Keith DA. 2002. Limits to the use of threatened species lists. Trends Ecol Evol 17: 503-507.

Ramarumo LJ, Maroyi A, Tshisikhawe MP. 2019a. Asparagus sekukuniensis (Oberm.) Fellingham \& N.L.Mey.: A threatened medicinal plant species used by Vhavenda in the Soutpansberg Region, Vhembe Biosphere Reserve, Limpopo Province, South Africa. J Appl Pharm Sci 9: 080-085.

Ramarumo LJ, Maroyi A, Tshisikhawe MP. 2019b. Bowiea volubilis Harv. ex Hook. f. subsp. volubilis: A therapeutic plant species used by the traditional healers in the Soutpansberg Region, Vhembe Biosphere Reserve, Limpopo Province, South Africa. J Pharm Sci Res 11: 2538-2542.

Ramarumo LJ, Maroyi A, Tshisikhawe MP. 2019c. Euphorbia pulvinata Marloth: A useful succulent plant species in Vhembe Biosphere Reserve, Limpopo Province, South Africa. Indian J Tradit Knowl 18: $122-126$.

Ramarumo LJ, Maroyi A, Tshisikhawe, MP. 2020. Plant species used for birdlime-making in South Africa. Bangladesh J Bot 49: 117-124.

Rampedi IT, Olivier J. 2013. Traditional beverages derived from wild food plant species in the Vhembe District, Limpopo Province in South Africa. Ecol Food Nut 52: 203-222.

Raustiala K, Victor DG. 1996. Biodiversity since Rio: the future of the Convention on Biological Diversity. Environ Sci Pol Sustain Dev 38: $16-45$

Raustiala K. 1997. Domestic institutions and international regulatory cooperation: comparative responses to the Convention on Biological Diversity. World Pol 49: 482-509.

Reyers B. 2004. Incorporating anthropogenic threats into evaluations of regional biodiversity and prioritisation of conservation areas in the Limpopo Province, South Africa. Biol Conserv 118: 521-531.

Rossi G, Orsenigo S, Montagnani C, Fenu G, Gargano D, Peruzzi L, Wagensommer RP, Foggi B, Bacchetta G, Domina G, Conti F. 2016 Is legal protection sufficient to ensure plant conservation? The Italian Red List of policy species as a case study. Oryx 50: 431-436.

Schatz GE. 2018. Plants on the IUCN Red List: setting priorities to inform conservation. Trends Plant Sci 14: 638-642.

Setshego MV, Aremu AO, Mooki O, Otang-Mbeng W. 2020. Natura resources used as folk cosmeceuticals among rural communities in Vhembe district municipality, Limpopo Province, South Africa. BMC Compl Med Therap 20: 81. DOI: 10.1186/s12906-020-2869-x

Shuaib M, Ahmed S, Ali K, Ilyas M, Hussain F, Urooj Z, Shah SS, Kumar T, Shah M, Khan I, Hussain F. 2019. Ethnobotanical and ecological assessment of plant resources at District Dir, Tehsil Timergara, Khyber Pakhtunkhwa, Pakistan. Acta Ecol Sinica 39: 109-115.

Singh AP, Kumar M, Nagar B, Pala NA, Bussmann RW. 2019 Ethnomedicinal use of plant resources in Kirtinagar Block of Tehri Garhwal in Western Himalaya. Ethnobot Res Appl 18: 1-11.

Slik JF, Arroyo-Rodríguez V, Aiba SI, Alvarez-Loayza P, Alves LF, Ashton P, Balvanera P, Bastian ML, Bellingham PJ, Van Den Berg E, Bernacci L. 2015. An estimate of the number of tropical tree species. Proc Nat Acad Sci 112: 7472-7477.

Smith FD, May RM, Pellew R, Johnson TH, Walter KR. 1993. How much do we know about the current extinction rate?. Trends Ecol Evol 8: 375-378.

Sun Z, Liu X, Schmid B, Bruelheide H, Bu W, Ma K. 2017. Positive effects of tree species richness on fine-root production in a subtropica forest in SE-China. J Plant Ecol 10: 146-157.

Talaat WIAW. 2013. Protection of the associated traditional knowledge on genetic resources: beyond the Nagoya Protocol. Proc Soc Behav Sci 91: 673-678.

Taylor PJ, Sowler S, Schoeman MC, Monadjem A. 2013. Diversity of bats in the Soutpansberg and Blouberg Mountains of northern South Africa: complementarity of acoustic and non-acoustic survey methods. S Afr J Wildlife Res 43: 12-26.
Telwala Y, Brook BW, Manish K, Pandit MK. 2013. Climate-induced elevational range shifts and increases in plant species richness in a Himalayan biodiversity epicentre. PLoS One 8: e57103. DOI: 10.1371/journal.pone.0057103.

Tengö M, Brondizio ES, Elmqvist T, Malmer P, Spierenburg M. 2014. Connecting diverse knowledge systems for enhanced ecosystem governance: the multiple evidence base approach. Ambio 43: 579591

Tesfaye G, Teketay D, Fetene M, Beck E. 2010. Regeneration of seven indigenous tree species in a dry Afromontane forest, southern Ethiopia. Flora Morphol Dis Fun Ecol Plants 205: 135-143.

Tiawoun MAP, Tshisikhawe MP, Gwata ET. 2018. A Review on Yellow Peeling Plane (Brackenridgea zanguebarica Oliv.): A Critically Endangered Endemic Plant Species. Ann Res Rev Biol 29: 1-13.

Tiawoun MAP, Tshisikhawe MP, Gwata ET. 2019. Investigation of current threats to the existence of Brackenridgea zanguebarica in a small geographic area in Vhembe, Limpopo Province, South Africa. Biodiversitas 20: 1487-1495.

Trouwborst A. 2010. Managing the carnivore comeback: international and EU species protection law and the return of lynx, wolf and bear to Western Europe. J Environ Law 22: 347-372.

Tshisikhawe MP, Malunga G. 2017. Ethnobotanical profile of indigenous tree species protected within dryland agricultural farming system. J Agric Allied Sci 6: 15-21.

Tshisikhawe MP, Van Rooyen MW, Gaugris JY. 2013. Is the present Brackenridgea Nature Reserve large enough to ensure the survival of Brackenridgea zanguebarica Oliv.?. Koedoe 55: 1-5.

Tuttolomondo T, Licata M, Leto C, Savo V, Bonsangue G, Gargano ML, Venturella G, La Bella S. 2014. Ethnobotanical investigation on wild medicinal plants in the Monti Sicani Regional Park (Sicily, Italy). J Ethnopharmacol 153: 568-586.

Ullah S, Khan MR, Shah NA, Shah SA, Majid M, Farooq MA. 2014. Ethnomedicinal plant use value in the Lakki Marwat District of Pakistan. J Ethnopharmacol 158: 412-422.

Umair M, Altaf M, Abbasi AM. 2017. An ethnobotanical survey of indigenous medicinal plants in Hafizabad district, Punjab-Pakistan. PLoS One 12: e0177912.

Valiente-Banuet A, Aizen MA, Alcántara JM, Arroyo J, Cocucci A Galetti M, García MB, García D, Gómez JM, Jordano P, Medel R. 2015. Beyond species loss: the extinction of ecological interactions in a changing world. Fun Ecol 29: 299-307.

Van Wyk BE. 2015. A review of commercially important African medicinal plants. J Ethnopharmacol 176: 118-134.

Vetaas OR, Grytnes JA. 2002. Distribution of vascular plant species richness and endemic richness along the Himalayan elevation gradient in Nepal. Global Ecol Bio 11: 291-301.

Vhembe District Municipality. 2019. DC 34 Vhembe Final IDP 2017/182021/22. https: //municipalities.co.za/resources/129/vhembe-districtmunicipality [29 October 2019].

Von Glasenapp M, Thornton TF. 2011. Traditional ecological knowledge of Swiss alpine farmers and their resilience to socioecological change. Human Ecol 39: 769-781.

Walsh JC, Watson JE, Bottrill MC, Joseph LN, Possingham HP. 2013. Trends and biases in the listing and recovery planning for threatened species: an Australian case study. Oryx 47: 134-143.

Weber MA, Ringold PL. 2019. River metrics by the public, for the public. PLoS One 14: e0214986. DOI: 10.1371/journal.pone.0214986

Whittaker RJ, Araújo MB, Jepson P, et al. 2005. Conservation biogeography: assessment and prospect. Div Distr 11: 3-23.

Williams VL, Victor JE, Crouch NR. 2013. Red listed medicinal plants of South Africa: status, trends, and assessment challenges. S Afr J Bot 86: 23-35.

Xu W, Xiao Y, Zhang J, et al. 2017. Strengthening protected areas for biodiversity and ecosystem services in China. Proc Nat Acad Sci USA 114: 1601-1606. 